Reprod. Nutr. Dévelop., 1984, 24 (5A), 609-621.

\title{
A single-unit analysis of reciprocal relationships between the lateral and medial hypothalamus in rats
}

\author{
T. ROESCH ( $\left.{ }^{1}\right)$, Bernadette FÉLIX (2)
}

Laboratoire de Physiologie des Centres Nerveux Université Pierre et Marie Curie

4. place Jussieu, 75230 Paris, France.

Summary. The spontaneous activity of hypothalamic units was studied in chronic awake and ketamine-anaesthetized rats. Ketamine appeared to decrease significantly the spontaneous firing of neurons in the ventromedial hypothalamic nucleus (VMH) but did not influence the activity in either the dorsomedial hypothalamic nucleus (DMH) or the lateral hypothalamic area (LHA). The responses obtained in the medial hypothalamus and the LHA after stimulation of the LHA and VMH, respectively, were not modified in either of the recording conditions. These responses corresponded to a pause in spontaneous activity, sometimes associated with a short-latency excitatory response, orthodromic or antidromic. The possibility of direct reciprocal connections between the LHA and the VMH has been discussed on the basis of electrophysiological and anatomical studies.

\section{Introduction.}

A early as 1939, Heterington and Ranson induced hyperphagia in rats by making electrolytic lesions in the ventromedial hypothalamic nucleus (VMH); their observations have been largely confirmed in different mammalian species (Anand et al., 1955) and birds (Lepkowski and Yasuda, 1966 ; Félix et al., 1980). Hyperphagia has been observed also following stimulation of the lateral hypothalamic area (LHA) (Delgado and Anand, 1953) and even in satiated animals (Miller, 1960 ; Smith, 1956). The opposite effects, hypophagia or aphagia, can be induced by lesions in the LHA (Anand and Brobeck, 1951) or by stimulation of the $\mathrm{VMH}$ (Oomura et al., 1964, 1967).

On the other hand, the "dual conception " postulated by Anand and Brobeck (1951) considers that the VMH, "the satiety center ", inhibits the LHA, " the feeding center ". This concept implies that direct connections exist between the $\mathrm{VMH}$ and the LHA. Behavioural and anatomical results make it difficult to accept the concept of well defined and localized feeding and satiety centers, and

(1) D.G.R.S.T. Fellow.

(2) Permanent address : Laboratoire de Physiologie de la Nutrition, I.N.R.A., 78350 Jouy-enJosas. To whom reprint requests should be addressed. 
reports on the existence of such connections are contradictory. While hyperphagia has been observed following knife cuts between the $\mathrm{VMH}$ and the LHA (Albert and Storlien, 1969 ; Gold, 1970 ; Sclafani and Grossman, 1969), Sclafani and Maul (1974) found that, after the sections, stimulation of the VMH produced hypophagia as it does in normal animals. This suggested that relay structures are involved in mediolateral hypothalamic relations. Moreover, the animals rendered hyperphagic by $\mathrm{VMH}$ lesions still ate meals, indicating that the arrest and releasing mechanisms of food intake still functioned.

Electrophysiological studies on the single-unit activity of the LHA and medial hypothalamic nuclei with their recriprocal influences have only been performed in cats. Oomura et al. (1964, 1967) analysed spontaneous unit discharges recorded simultaneously from the LHA and the VMH. They reported that repetitive electrical stimulation in one region increased single-unit discharge in that area but at the same time decreased single-unit discharge in the other structure. These results were partially contradicted by the investigations of Murphy and Renaud (1969) but have been confirmed by Van Atta and Sutin (1971).

These areas have not been investigated in rats. In the present study, we have examined single-unit activity in the LHA and medial hypothalamic neurons and the modification in cellular activity occuring in the cells of one structure when an electrical stimulation was applied to the other structure. The experiments were performed in both anaesthetized and chronic awake rats.

\section{Material and methods.}

The experiments were carried out on 21 anaesthetized and 7 chronic awake male Sprague-Dawley rats weighing between 230 and $250 \mathrm{~g}$. Both hemispheres of the anaesthetized animals were investigated over two recording sessions, and between recording sessions both chronic and acute animals were allowed to eat and drink water ad libitum.

Acute experiments. - The rats were anaesthetized with intraperitoneal injections of ketamine $(100 \mathrm{mg} / \mathrm{kg})$. Additional intramuscular injections were administered during the experiment in order to maintain a stable level of anaesthesia. Before surgery the edges of the incisions and auditory canals were infiltrated with $0.2 \%$ xylocaine. Heart rate was monitored continuously and body temperature was maintained between 37 and $38^{\circ} \mathrm{C}$ by means of a hot-water circulating pad. The rats were fixed in a conventional stereotaxic apparatus with the head positioned as required for the use of the stereotaxic atlas of AlbeFessard et al. (1966). The skull was then removed over the regions from which recordings were to be made (VMH : A 5.6 to $6.6 ; \mathrm{L} 0.1$ to 1.5 - LHA : A 5.6 to $6.6 ; \mathrm{L} 1.25$ to 2.25 ). Stimulating electrodes were introduced into the LHA (A 5.6 to $6.6 ; \mathrm{L} 1.7$ to $2.2 ; \mathrm{H}+1.7$ to +2.8 ) or the $\mathrm{VMH}$ (A 5.6 to $6.6 ; \mathrm{L} 0.5$ to 1.0 ; $\mathrm{H}+1.1$ to 2$)$ through small holes in the skull.

Electrical stimulation was applied through bipolar concentric stainless steel electrodes (diameter : $400 \mu \mathrm{m}$; internal electrode diameter : $125 \mu \mathrm{m}$; intertip distance : $300 \mu \mathrm{m}$; electrode tip : $40 \mu \mathrm{m}$ ) which had a resistance of $30-50000 \Omega$ 
measured in saline. Single $(0.5$ to $2 \mathrm{~Hz})$ rectangular pulses of $50-500 \mu \mathrm{A}$ intensity and 0.2 to $0.5 \mathrm{msec}$ duration were applied through a stimulus isolation unit.

Single-unit activity was recorded extracellularly with glass micropipettes (tip diameter : $1-3 \mu \mathrm{m}$ ) filled with $1 \%$ Pontamine sky blue dissolved in $1 \mathrm{M} \mathrm{KCl}$ solution. Their impedance ranged from 7 to $10 \mathrm{M} \Omega$ at $1000 \mathrm{~Hz}$. The micropipettes were connected by a chlorided silver wire to a preamplifier and an amplifier with variable band pass. The amplifier output was connected to an audiomonitor and an oscilloscope for observation and photography.

An iontophoretic deposit of Pontamine blue was made at the end of each microelectrode track ( 2 to $30 \mu \mathrm{A}$ for $20 \mathrm{~min}$ ). At the end of each experiment, the site of stimulation was marked by an iron deposit using and anodal DC current of $5 \mathrm{~mA}$ for $10 \mathrm{sec}$.

The rats were then perfused through the left ventricle with a $10 \%$ formalin$1 \%$ ferro-cyanide solution. The brains were removed and stored in a $10 \%$ solution of formalin for at least $48 \mathrm{~h}$. Serial sections of $100 \mu \mathrm{m}$ were cut on a freezing microtome and stained with cresyl violet. The location of the electrodes was determined microscopically and indicated on drawings of appropriate sections of the brain. The positions of all the units recorded along the tracks were calculated, taking into account the position of the dye marks and the micromanipulator readings.

Chronic experiments. - In these experiments we used the preparation described by Sapienza et al. (1981) which allowed the use of classical HorsleyClarke coordinates.

After implantation of the head-support under ketamine anaesthesia, the rats were returned to their cages. Following a recovery period of 2-3 days, each rat was fixed by means of 4 bars adapted to the stereotaxic apparatus. An average of 8-9 microelectrode penetrations were made, usually 1 to 3 tracks a day. All other experimental procedures were the same as those used in the acute experiments, including recording and stimulating parameters and histological treatment.

Results.

1) Influence of ketamine anaesthesia on hypothalamic spontaneous single-unit activities.

Figure 1 presents the average frequencies of spontaneous single-unit discharges in the $\mathrm{VMH}$ nucleus, the dorsomedial hypothalamic nucleus (DMH) and the LHA for both anaesthetized and chronic awake rats. The cellular activity in chronic animals was recorded when they were awake and calm but never when they were asleep. These data demonstrate that ketamine significantly reduced $(P<$ $0.01)$ the spontaneous discharge of units in the VMH from a mean value of $78 \pm$ 18 in chronic rats to $22 \pm 5$ spikes/10 sec in anaesthetized ones. On the other hand, ketamine tended to increase spontaneous neural activity in the DMH nucleus and to decrease it in the LHA, but these differences were not statistically significant in the two types of preparation. 
The firing rate of $\mathrm{VMH}$ units in anaesthetized rats was significantly slower than for the DMH $(P<0.005)$ and the LHA $(P<0.05)$ units; thus $\mathrm{VMH}$ neurons could be easily recognized and their location prejudged before histological control. It was also interesting that the various responses to stimulation were identical in chronic as well as in anaesthetized rats. Therefore, no distinction was made between the two preparations (chronic and anaesthetized rats) in the presentation of the results.

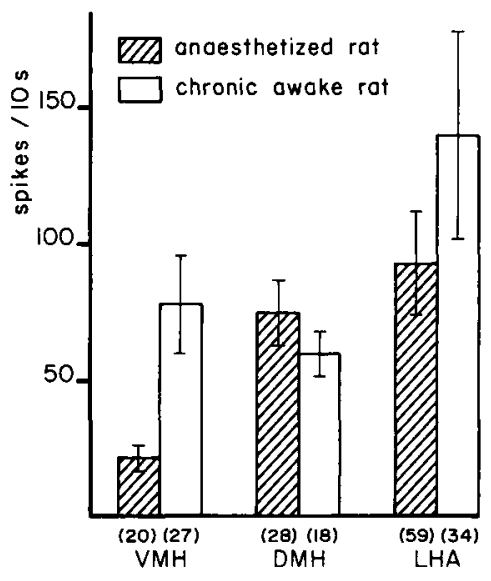

FIG. 1. - Histogram of spontaneous discharge (spikes/ $10 \mathrm{sec}$ recorded within the rat hypothalamus: ventromedial nucleus (VMH), dorsomedial nucleus (DMH) and lateral hypothalamic area (LHA). Comparison between anaesthetized and chronic awake rats. The mean \pm SEM and the number of cells (in parenthesis) are given for each structure and type of preparation.

2) Effect on lateral hypothalamic neuronal activity of ventromedial hypothalamic nucleus stimulation.

In 13 rats we were able to study 67 LHA neurons. Of these, 51 responded to stimulation of the $\mathrm{VMH}$. The positioning of all the cells and stimulating sites were
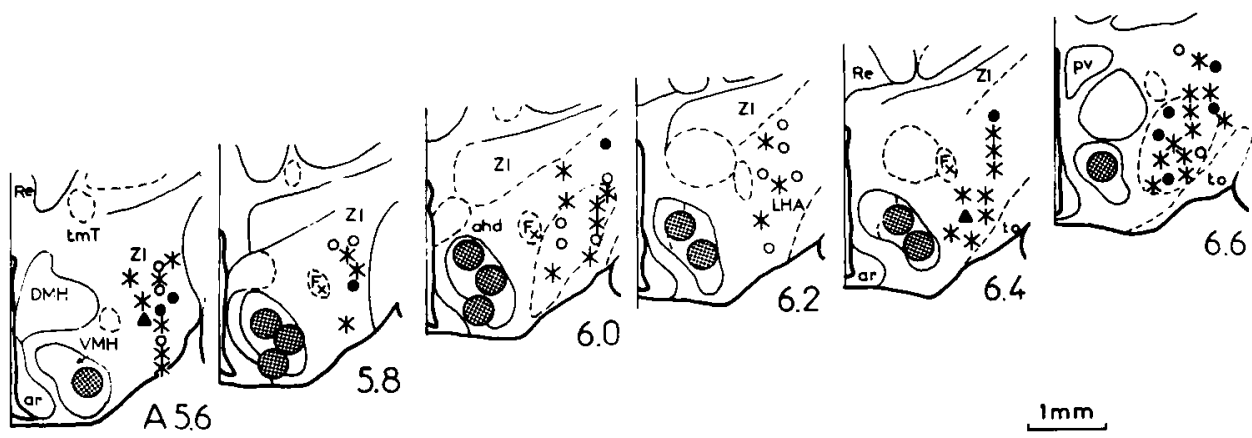

FIG. 2. - VMH stimulation sites and location of the different types of cell response recorded in the

LHA are illustrated on serial sections.

* pause response : orthodromic activation + pause response : - antidromic activation + pause response ; $O$ unresponsive neuron; location of the tip of the stimulating electrode marked by an electrolytic lesion.

List of abbreviations for this figure and the following ones : ahd : area hypothalamica dorsalis ; LHA : area hypothalamica lateralis ; ar : nucleus arcuatus; DMH : nucleus dorsomedialis hypothalami ; Fx : fornix ; pv : nucleus paraventricularis hypothalami ; Re : nucleus reuniens ; $t \mathrm{mT}:$ tractus mamillo thalamicus; to : tractus opticus; $\mathrm{VMH}$ : nucleus ventromedialis hypothalami ; $\mathrm{ZI}$ : zona incerta. 
plotted on drawings of hypothalamic sections and the responsive cells classified as a function of their type of response (fig. 2). The fiber units, recognized by the duration and form of their spikes, have not been reported here (Azerad et al., 1977). Thirty-nine cells presented a silence in their activity, 10 cells had a silent phase with an orthodromic response and 2 cells had a silent phase with an antidromic response. Table 1 shows the characteristics of the different types of cell response.

TABLE 1

Effects on LHA neuronal activity of VMH electrical stimulation. When the population of cells is sufficient, mean \pm SEM is given for the different response characteristics.

\begin{tabular}{ccccc}
\hline $\begin{array}{c}\text { Effect of VMH } \\
\text { stimulation }\end{array}$ & $\begin{array}{c}\text { Number of } \\
\text { cells }\end{array}$ & $\begin{array}{c}\text { Latency } \\
\text { (msec) }\end{array}$ & $\begin{array}{c}\text { Duration } \\
\text { (msec) }\end{array}$ & $\begin{array}{c}\text { Post-excitatory } \\
\text { arrest of } \\
\text { activity (msec) }\end{array}$ \\
\hline $\begin{array}{c}\text { Arrest of } \\
\text { activity }\end{array}$ & 1 & $<0.5$ & Complete & - \\
\cline { 2 - 4 } & 14 & $<0.5$ & $70 \pm 8$ & - \\
\hline $\begin{array}{c}\text { Orthodromic } \\
\text { activation }\end{array}$ & 10 & $12 \pm 1.5$ & & - \\
\hline $\begin{array}{c}\text { Antidromic } \\
\text { activation }\end{array}$ & 2 & $6 \pm 1$ & - & $53 \pm 15$ \\
\hline $\begin{array}{c}\text { Unresponsive } \\
\text { Cells }\end{array}$ & 16 & 1 & - & 50 \\
\hline
\end{tabular}

Arrest of cellular activity. - As seen on figure 3, we were able to distinguish 3 such types of response. Only one cell was completely silent during repetitive stimulation at $1 \mathrm{impulse} / \mathrm{sec}$ and started firing again when stimulation ceased. Thirty-eight cells presented a silent period with a duration ranging from 20 to 200 msec (mean $70 \pm 8 \mathrm{msec}$ ). While 24 cells had a silent phase after a latency of $12 \pm 1.5$ msec 14 cells presented a pause immediately after stimulation (fig. 3B), and 4 of these cells showed an enhancement of their discharge frequency following the silent period (fig. 3A). However, no correlation between the duration of the silent period and the presence of the delayed response could be found.

Excitatory responses and pause. - These responses were of two types, orthodromic and antidromic, the majority being orthodromic with a latency of 3 to $25 \mathrm{msec}$ (mean : $6 \pm 1 \mathrm{msec}$ ). The excitatory responses were always followed by a silent period lasting 15-150 msec (mean : $53 \pm 15 \mathrm{msec}$ ) (fig. 3D). 


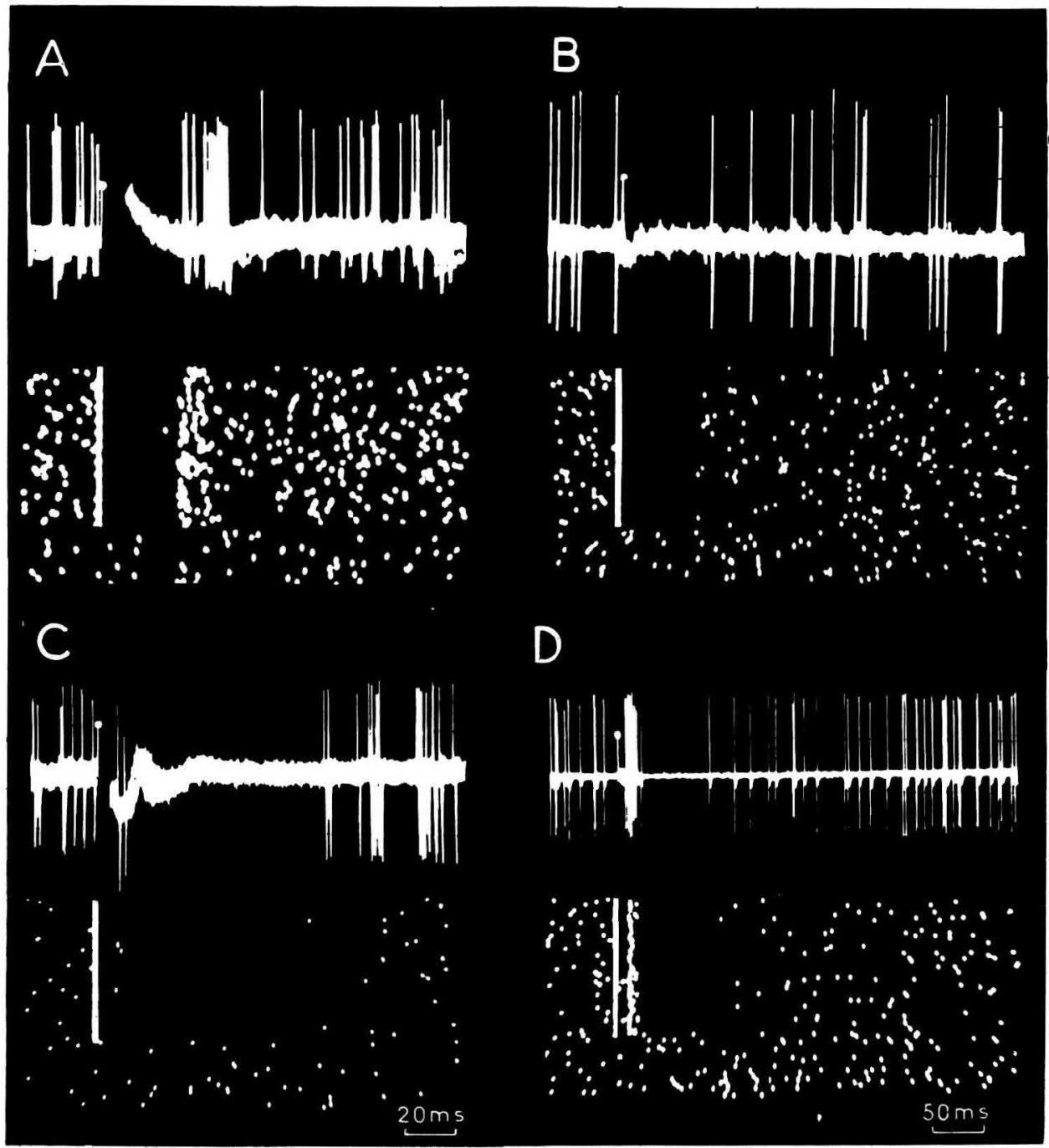

FIG. 3. - VMH stimulation induced different types of arrest in the spontaneous activity of LHA neurone: in $A$, this pause in firing was followed by a post-excitatory response, in $C$ the cell continued to discharge for a brief period after stimulation, and in $D$ an excitatory response appeared with a short latency.

Each type of response is presented in the form of ten superimposed traces (upper image) and in a raster display (lower image) where the stimulus artefact is represented by the vertical line.

Two antidromic responses were recorded with latencies of 5 and $1 \mathrm{msec}$ followed by a silent interval of 50 and $100 \mathrm{msec}$, respectively. The criteria for antidromic activation were evoked responses at a constant latency, ability to follow high-frequency stimulation and the collision of spontaneous spikes with antidromically evoked spikes (fig. 4). The latencies of the antidromic responses and the distance between the recording and stimulating sites gave estimates of conduction velocity of 0.2 and $1.5 \mathrm{~m} / \mathrm{sec}$. 


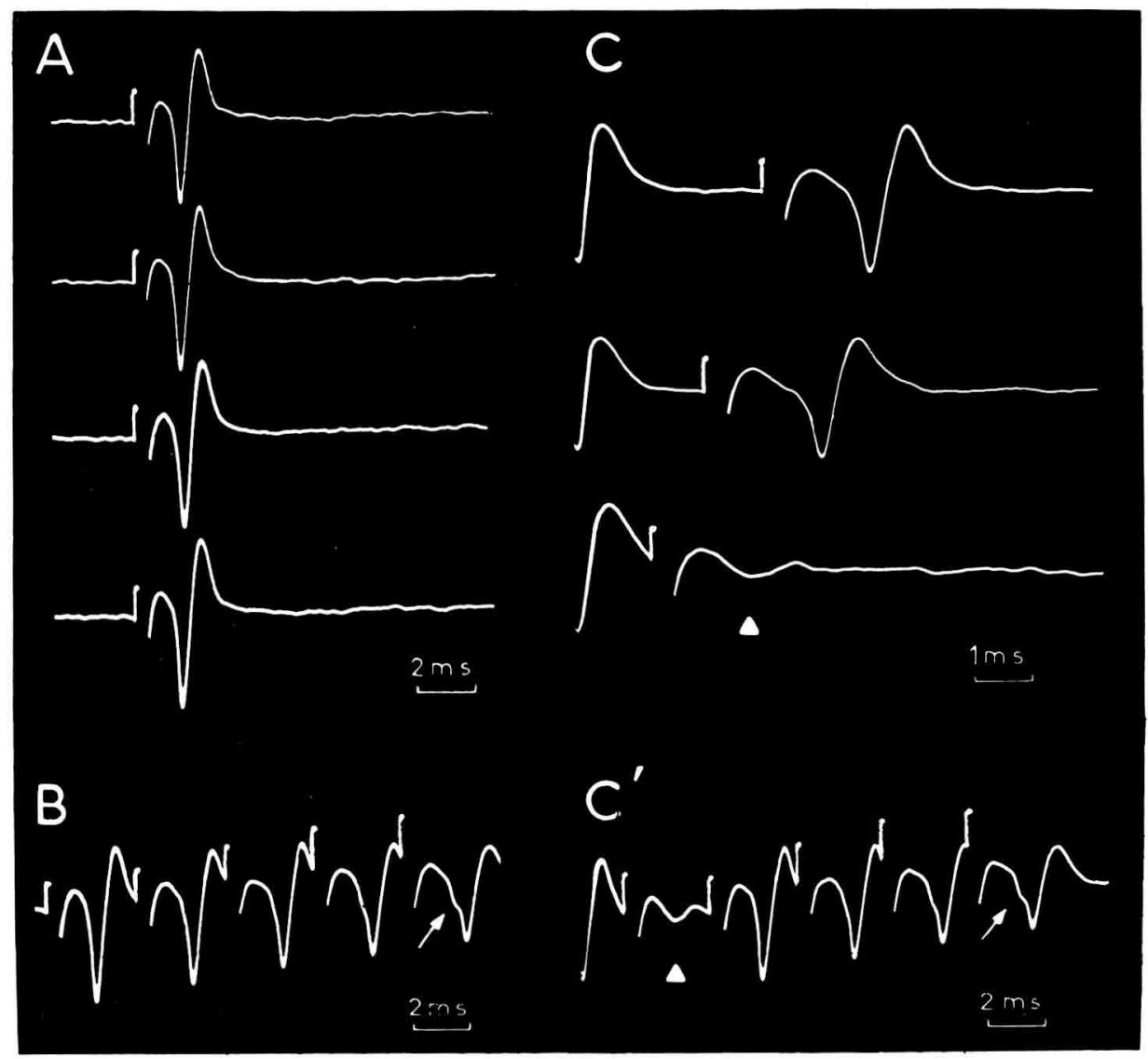

FIG. 4. - Example of an antidromic response with short and fixed latency (A) following rapid stimulation (B).

C-C' : each trace is triggered by a spontaneous spike. In $\mathrm{C}$, the time between triggering spike and stimulus is progressively reduced. When the distance between the spontaneous spike and the stimulus is of the order of the antidromic spike latency, the antidromic spike collides with the orthodromic spike (triangle). In $\mathrm{C}^{\prime}$ repetitive stimulation was applied and the first antidromic response collided with a spontaneous spike.

The appearance of the axonal segment is indicated by an arrow in B and $C^{\prime}$.

\section{3) Effects on medial hypothalamic neuronal activity of lateral hypothalamic area} stimulation.

Seventy-six medial hypothalamic neurons were recorded in 15 rats. Of these, 48 cells responded to stimulation of the LHA. The location of the stimulation sites and the distribution of the 76 cells were plotted (fig. 5). These neurons were distributed inside the medial hypothalamus as follows; ventromedial nucleus (VMH : 37), dorsomedial nucleus (DMH : 26), paraventricular nucleus (pv: 6), periventricular zone (PV: 3), arcuate nucleus (ar : 2) and dorsal area (ahd : 2). Table 2 shows the different characteristics of the responses of cells in the DMH and the $\mathrm{VMH}$. 
TABLE 2

Effects on VMH and DMH neuronal activity of LHA stimulation. When the population of cells is sufficient, mean \pm SEM is given for the different response characteristics.

\begin{tabular}{|c|c|c|c|c|c|c|c|c|}
\hline \multirow{2}{*}{$\begin{array}{l}\text { Effects of } \\
\text { LHA } \\
\text { stimulation }\end{array}$} & \multicolumn{4}{|c|}{ VMH } & \multicolumn{4}{|c|}{ DMH } \\
\hline & $\begin{array}{l}\text { Number } \\
\text { of cells }\end{array}$ & $\begin{array}{l}\text { Latency } \\
\text { (msec) }\end{array}$ & $\begin{array}{l}\text { Duration } \\
\text { (msec) }\end{array}$ & $\begin{array}{l}\text { Post-excitatory } \\
\text { arrest of } \\
\text { activity (msec) }\end{array}$ & $\begin{array}{l}\text { Number } \\
\text { of cells }\end{array}$ & $\begin{array}{l}\text { Latency } \\
\text { (msec) }\end{array}$ & $\begin{array}{l}\text { Duration } \\
\text { (msec) }\end{array}$ & $\begin{array}{l}\text { Post-excitatory } \\
\text { arrest of } \\
\text { activity (msec) }\end{array}$ \\
\hline \multirow{3}{*}{$\begin{array}{l}\text { Arrest of } \\
\text { activity }\end{array}$} & 6 & $<0.5$ & Complete & - & - & - & - & - \\
\hline & 14 & $<0.5$ & $-38 \pm 4$ & - & 9 & $<0.5$ & \multirow{2}{*}{$37 \pm 8$} & - \\
\hline & 3 & 5 to 10 & & - & 3 & 6 to 10 & & - \\
\hline \multirow{3}{*}{$\begin{array}{l}\text { Orthodromic } \\
\text { activation }\end{array}$} & \multirow{3}{*}{3} & 10 & 10 & 20 & \multirow{3}{*}{1} & \multirow{3}{*}{3} & \multirow{3}{*}{2} & \multirow{3}{*}{25} \\
\hline & & 5 & 7 & 40 & & & & \\
\hline & & 20 & 8 & 180 & & & & \\
\hline $\begin{array}{l}\text { Antidromic } \\
\text { activation }\end{array}$ & 1 & 5 & - & 80 & - & - & - & - \\
\hline $\begin{array}{l}\text { Unresponsive } \\
\text { cells }\end{array}$ & 10 & - & - & - & 13 & - & - & - \\
\hline
\end{tabular}

Arrest of cellular activity. - Forty-two of the cells recorded presented a silent phase following LHA stimulation. The types of pause were similar to those obtained in the LHA after VMH stimulation (fig. 3). Seven cells $(6$ in the VMH and 1 in the pv) stopped firing completely during repetitive stimulation at 1 impulse/sec. The remaining 35 cells were located as follows : $\mathrm{VMH}$ (17), $\mathrm{DMH}$ (12), pv (2), PV (2), ar (1), ahd (1). Except for 7 cells in which the silent period had a latency of 5 to $10 \mathrm{msec}$ all the others became silent immediately after
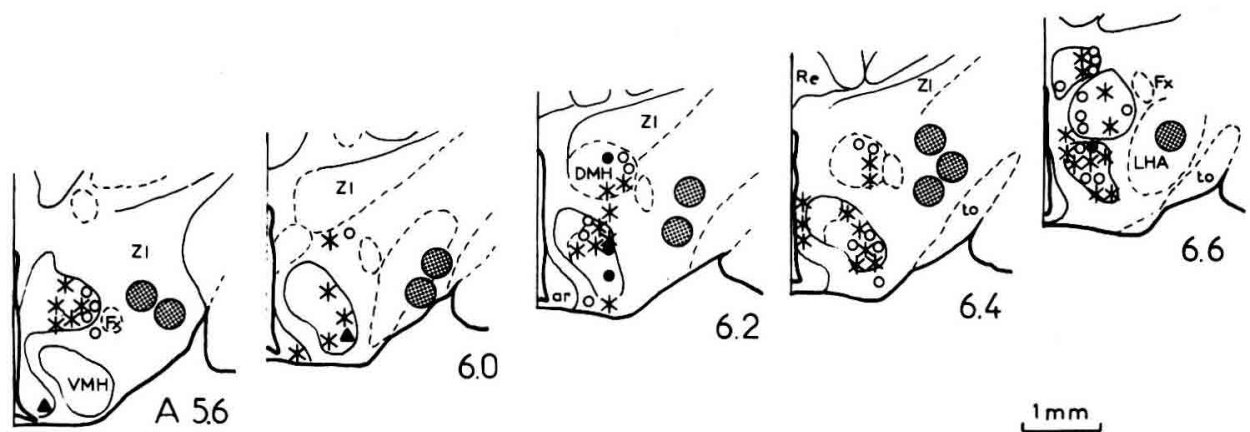

FIG. 5. - LHA stimulation sites and location of the different types of cell response recorded in medial hypothalamus are illustrated on serial sections.

(legend: see fig. 2). 
stimulation. The duration of the silent phases ranged between 20 and $80 \mathrm{msec}$ and no significant difference could be observed between the $\mathrm{VMH}$ units $(\mathrm{n}=17$; mean : $38 \pm 4 \mathrm{msec}$ ) and DMH units ( $=12$; mean : $37 \pm 8 \mathrm{msec}$ ). Only one cell, recorded in the ahd presented a silent phase of much longer duration (350 msec) and at a latency of $15 \mathrm{msec}$. The discharge of three DMH and $2 \mathrm{VMH}$ neurons was enhanced after the silent period.

Excitatory responses. - Four orthodromic and 2 antidromic responses were recorded and identified in the medial hypothalamus after LHA stimulation. The orthodromic responses (3-8 msec latency) were located in the VMH (3) and the $\mathrm{DMH}$ (1) and were always followed by a silent period lasting 20 to $180 \mathrm{msec}$.

We were able to identify 2 antidromically activated cells, 1 within the $\mathrm{VMH}$ (5 msec latency) and 1 within the ar $(7.5 \mathrm{msec}$ latency). From these latencies, conduction velocity was estimated to be less than $0.5 \mathrm{~m} / \mathrm{sec}$.

\section{Discussion.}

Anaesthesia and hypothalamic neuronal activity. - Our experiments clearly show the influence of ketamine anaesthesia on hypothalamic neuronal activity. It appears that ketamine significantly reduced single-unit activity in the VMH but not in the DMH or LHA. Similar observations have been reported for the VMH in cats under light and deep ether anaesthesia (Oomura et al., 1964, 1967). However, while anaesthesia enhanced spontaneous activity in the LHA of cats, this was not the case in rats anaesthetized with ketamine. This indicates that different anaesthetics produce various effects on hypothalamic neuronal activity. But as no significant difference was observed in the responses obtained in the ketamine-anaesthetized and chronic awake rats, this demonstrates that these responses were not an artefact due to the type of anaesthesia used.

Influence of the VMH on the LHA. - A high percentage of the lateral hypothalamic area neurons $(76 \%)$ presented a pause in their spontaneous firing in response to $\mathrm{VMH}$ stimulation. Orthodromic or antidromic responses were rarely obtained. These results are in good agreement with those reported for cats (Oomura et al., 1967; Van Atta and Sutin, 1971), even though the effect of electrical stimulation of the VMH on LHA cells seemed more powerful in rats. This phenomenon could be explained either by a local inhibitory process or by a disfacilitation produced on a relay which could have a tonic facilitatory influence on these cells. As these experiments were performed using extracellular recordings, we are unable to state whether this pause in neuronal activity was due to a true inhibition or not.

Some units in the LHA continued to discharge for a brief period following stimulation before a silent phase appeared; this fact suggests that at least one relay was involved in this type of response. On the other hand, the VMH cells had a silent phase occuring immediately after LHA stimulation, and one cell recorded in the $\mathrm{VMH}$ could be antidromically activated by LHA stimulation. This would indicate that fibers which connect the VMH directly with the LHA exist, even

Reproduction, Nutrition, Développement n 5 A 1984. - 8. 
though they appear to be scarce. However, this cell population presents a slow firing rate; consequently, some neurons may not have been detected by extracellular recording, and the number of units antidromically activated must be considered as an underestimation of the percentage of $\mathrm{VMH}$ cells directly projecting to the LHA.

In summary, these data lead to the conclusion that connections from the VMH to the LHA exist through which VMH stimulation leads to blocking or reduction of LHA cellular activity. Both direct and indirect connections between the VMH and LHA appear to be present. The existence of such direct connections has already been postulated by several authors (Arees and Mayer, 1967 ; Barone et al., 1981 ; Berk and Finkelstein, 1982 ; Kita and Oomura, 1982b ; Saper et al., 1976). Only Luiten and Room (1980) have denied any direct projections of the $\mathrm{VMH}$ to the LHA on the basis of an anatomical study using retrograde transport of HRP.

Influence of the LHA on the MBH. - Stimulation of the LHA also produced a pause in the activity of a high percentage of dorsomedial and ventromedial cells $(63 \%)$, but few of these responses were preceded by either orthodromic or antidromic activation. These results are similar to those reported in cats by Oomura et al. (1967). However, Murphy and Renaud (1969) found a pause in VMH cell activity only after stimulating the most ventral and medial part of the LHA ; these authors suggested that « the ability of LHA stimulation to inhibit the firing of ventromedial neurons would appear to be a function of the proximity of the stimulating electrode to the dentritic terminals of the inhibitory interneurons or pathways synaptically exciting the terminals ». Indeed, Millhouse (1973) found neurons in the LHA whose dendrites swing out ventrally and laterally into the LHA. However, examination of our stimulating electrode sites in rats (fig. 5) shows that the efficient stimulations were usually located in the dorsolateral part of the LHA.

The fact that two LHA cells could be antidromically activated by VMH stimulation and that most of the tested cells in the $\mathrm{VMH}$ nucleus presented a silent phase occuring immediately after VMH stimulation indicates that the LHA projects directly onto the VMH. Kita and Oomura (1982a, b) and Millhouse (1973) have reported a sparse number of fibers projecting from the LHA to the VMH. Millhouse (1973) also observed that most of the fibers composing the VMH capsule had numerous " boutons en passant 》 and short ramified collaterals and were not fibers of passage. The sparseness of these direct connections could explain the contraversial neuroanatomical results, i. e. Eager et al. (1971) and Saper et al. (1979) reported projections, while Wolf and Sutin (1966), Chi (1970) and Luiten and Room (1980) did not find them.

The orthodromic responses we have found also suggest some projections from the LHA to the VMH. These responses were always followed by a postexcitatory pause. Latencies were longer for the pauses than for the excitations, suggesting that these arrests in activity resulted from di or polysynaptic connections: when a VMH neuron is excited, a collateral could stimulate an inhibitory interneuron which, in turn, could depress cellular activity. Murphy and Renaud (1968) have already postulated the existence of such interneurons. 
However, the arrest of firing, which appears most frequently, could also be due to the stimulation of fibers of passage coming from the medial forebrain bundle which, according to Papir-Kricheli and Feldman (1980), have an inhibitory effect on spontaneous VMH activity.

The results we present here complete previous anatomical and electrophysiological studies which favour a functional coupling of the $\mathrm{VMH}$ and the LHA. However, it is impossible to deny the possibility that one or more relays are involved in the pathways mediating some of the responses we obtained. Luiten and Room (1980) suggested that a relay function between the LHA and the $\mathrm{VMH}$ could be attributed to $\mathrm{DMH}$ cells which maintain reciprocal connections with both of those areas. Their suggestion has received some support in the literature (Barone et al., 1981 ; Chi, 1970 ; Millhouse, 1973 ; Saper et al., 1979), but also some criticism (Berk and Finkelstein, 1982 ; Kita and Oomura, 1982a). The silent phase we obtained in many dorsomedial cells after stimulation of the LHA favours a role of the DMH, but we did not find antidromically activated cells. Recent behavioural studies (Gold et al., 1977 ; Leibowitz, 1979) supported by anatomical investigations (Berk and Finkelstein, 1982 ; Silverman et al., 1981) have also introduced the paraventricular nucleus as an important link in feeding behaviour. Many structures known to be in relation with the LHA and VMH could be candidates for relays, but no experiments have been done until now to prove or disprove this fact.

The responses we have obtained in rats indicate the existence of connections between the mediobasal and the lateral areas of the hypothalamus. Moreover, they show that direct and indirect pathways establish a reciprocal inhibitory relationship between these two regions.

Reçu en février 1984. Accepté en mai 1984

Acknowledgements. - The authors wish to thank Prof. D. Albe-Fessard for helpful guidance in these experiments and her constructive comments on the preparation of this text. They warmly thank Mrs Pamela Sanderson who kindly corrected the English of the text.

Résumé. Analyse unitaire des interrelations entre l'hypothalamus médian et latéral chez le rat.

L'activité spontanée des neurones hypothalamiques a été étudiée chez le rat anesthésié par la kétamine et chez le rat éveillé en préparation chronique. La kétamine diminue le rythme de décharge des cellules du noyau ventromédian (VMH) de façon significative mais elle n'a pas d'influence sur celui des cellules du noyau dorsomédian (DMH) ni de l'aire hypothalamique latérale (LHA). De plus après stimulation de LHA et de VMH, les réponses obtenues dans l'hypothalamus médian et LHA respectivement, sont identiques pour les deux types de préparation. Ces réponses consistent le plus souvent en un arrêt d'activité qui peut être accompagné d'une excitation orthodromique ou antidromique, à courte latence. L'existence d'interconnexions directes ou non entre LHA et VMH est discutée sur la base d'études électrophysiologiques et anatomiques. 


\section{Références}

ALBE-FESSARD D., STUTINSKY F., LIBOUBAN S., 1966. Atlas stéréotaxique du diencéphale du rat blanc. Edition du C.N.R.S.

ALBERT D. J., STORLIEN L. H., 1969. Hyperphagia in rats with cuts between the ventromedial and lateral hypothalamus. Science, 165, 599-600.

ANAND B. K., BROBECK J. R., 1951. Hypothalamic control of food intake in rats and cats. Yale J. biol. Med., 24, 123-140.

ANAND B. K., DUA S., SHOENBERG K., 1955. Hypothalamic control of food-intake in cats and monkeys. J. Physiol. (London), 127, 143-152.

AREES E. A., MAYER J., 1967. Anatomical connections between medial and lateral regions of the hypothalamus concerned with food intake. Science, 157, 1574-1575.

AZERAD J., WODA A., ALBE-FESSARD D., 1977. Identification dans les enregistrements par microélectrodes de verre des activités recueillies au voisinage des axones et des corps cellulaires du complexe sensitif trigéminal. C. R. Acad. Sci., Paris, Sér. D, 285, 797-800.

BARONE F. C., WAYNER M. J., SCHAROUN S. L., GUEVARA-AGUILAR R., AGUILARBATURONI H. U., 1981. Afferent connections to the lateral hypothalamus : a horseradish peroxidase study in the rat. Brain Res. Bull., 7, 75-88.

BERK M. L., FINKELSTEIN J. A., 1982. Efferent connections of the lateral hypothalamic area of the rat : an autoradiographic investigation. Brain Res. Bull., 8, 511-526.

CHI C. C., 1970. Afferent connections to the ventromedial nucleus of the hypothalamus in the rat. Brain Res., 17, 439-445.

DELGADO J. M. R., ANAND B. K., 1953. Increase of food intake induced by electrical stimulation of the lateral hypothalamus. Am. J. Physiol., 172, 162-168.

EAGER R. P., CHI C. C., WOLF G., 1971. Lateral hypothalamic projections to the hypothalamic ventromedial nucleus in the albino rat : demonstration by means of a simplified ammoniacal silver degeneration method. Brain Res., 29, 128-132.

FELIX B., AUFFRAY P., MARCILLOUX J. C., 1980. Effect of induced hypothalamic hyperphagia and forced-feeding on organ weight and tissular development in Landes geese. Reprod. Nutr. Dévelop., 20, 709-717.

HETERINGTON A. W., RANSON S. W., 1939. Experimental hypothalamico-hypophyseal obesity in the rat. Proc. Soc. exp. Biol. Med., 41, 465-466.

GOLD R. M., 1970. Hypothalamic hyperphagia produced by parasagittal knife cuts. Physiol. Behav., 5, 23-25.

GOLD R. M., JONES A. P., SAWCHENKO P. E., 1977. Paraventricular area : critical focus of a longitudinal neurocircuitry mediating food intake. Physiol. Behav., 18, 1111-1119.

KITA H., OOMURA Y., 1982a. An HRP study of the afferent connections to rat medial hypothalamic region. Brain Res. Bull., 8, 53-62.

KITA H., OOMURA Y., 1982b. An HRP study of the afferent connections to rat lateral hypothalamic region. Brain Res. Bull., 8, 63-71.

LEIBOWITZ S. F., 1979. Functional and anatomical studies of noradrenergic system of the paraventricular hypothalamus that controls feeding behavior. Soc. Neurosci. Abstr., 5, 220.

LEPKOWSKI S., YASUDA M., 1966. Hypothalamic lesions, growth and body composition of male chickens. Poultry Sci., 45, 582-588.

LUITEN P. G. M., ROOM P., 1980. Interrelations between lateral, dorsomedial and ventromedial nuclei in the rat. An HRP study. Brain Res., 190, 321-332.

MILLER N. E., 1960. Motivational effects of brain stimulation and drugs. Fed. Proc., 19, 846-854.

MILLHOUSE O. E., 1973. The organization of the ventromedial hypothalamic nucleus. Brain Res., 55, 71-87.

MURPHY J. T., RENAUD L. P., 1968. Inhibitory interneurones in the ventromedial nucleus of the hypothalamus. Brain Res., 9. 385-389.

MURPHY J. T., RENAUD L. P., 1969. Mechanisms of inhibition in the ventromedial nucleus of the hypothalamus. J. Neurophysiol., 32, 85-102.

OOMURA Y., KIMURA K., OOYAMA H., MAENO T., IKI M., KUNIYOSHI M., 1964. Reciprocal activities of the ventromedial and lateral hypothalamic areas of cats. Science, 143, 484-485. 
OOMURA Y., OOYAMA H., YAMAMOTO T., NAKA F., 1967. Reciprocal relationship of the lateral and ventromedial hypothalamus in the regulation of food intake. Physiol. Behav., 2, 97-115.

PAPIR-KRICHELLI D., FELDMAN S., 1980. Spontaneous activity of mediobasal hypothalamic neurons following deafferentations and lesions. Brain Res. Bull., 5, 759-763.

SAPER C. B., SWANSON L. W., COWAN W. M., 1976. The efferent connections of the ventromedial nucleus of the hypothalamus of the rat. J. comp. Neurol., 169, 409-442.

SAPER C. B., SWANSON L. W., COWAN W. M., 1979. An autoradiographic study of the efferent connections of the lateral hypothalamic area in the rat. J. comp. Neurol., 183, 689-706.

SAPIENZA S., TALBI B., JACQUEMIN J., ALBE-FESSARD D., 1981. Relationship between input and output of cells in motor and somatosensory cortices of the chronic awake rat. Exp. Brain Res. . 43, 47-57.

SCLAFANI A., GROSSMAN S. P., 1969. Hyperphagia produced by knife cuts between the medial and lateral hypothalamus in the rat. Physiol. Behav., 4, 533-537.

SCLAFANI A., MAUL G., 1974. Does the ventromedial hypothalamus inhibit the lateral hypothalamus. Physiol. Behav., 12, 157-162.

SILVERMAN A. J., HOFFMAN D. L., ZIMMERMAN E. A., 1981. The descending afferent connections of the paraventricular nucleus on the hypothalamus (P. V. N.). Brain Res. Bull., 6, 47-61.

SMITH O. A., 1956. Stimulation of lateral and medial hypothalamus and food intioke in the rat. Anat. Rec., 124, 363-364.

VAN ATTA L., SUTIN J., 1971. The response of single lateral hypothalamic neurons to ventromedial nucleus and limbic stimulation. Physiol. Behav., 6, 523-536.

WOLF G., SUTIN J., 1966. Fiber degeneration after lateral hypothalamic lesions in the rat. J. comp. Neurol., 127, 137-156. 